\title{
The Strengthening of Legal Politics Through Public Policy Control as a Prevention of Corruption in Economic Globalization Era
}

\author{
Ismunarno $^{1}$, Hartiwiningsih ${ }^{2}$, Isharyanto ${ }^{3}$ \\ ${ }^{1.2 .3}$ Universitas Sebelas Maret \\ Surakarta, Indonesia \\ 66ismunarno@gmail.com
}

\begin{abstract}
This study aimed (i) to find out the legal politics strengthening in the form of control toward public policy and (ii) to analyze the public policy control as a preventive attempt against corruption. Policies have been used as a "gate" to commit policy corruption. It is necessary to extend the definition of "accountability" in the corruption delict in order to build a logical argumentation regarding policies that are categorized into a criminal act. The present research was categorized as doctrinal research. The present research used primary legal materials (regulation and relevant documents) as a source of legal information, which were then qualitatively analyzed. The statute, comparative, and conceptual approaches were employed to solve the problems of the study. The result of the study showed that: (i) Legal political strengthening in the form of public policy control can be realized by maximizing the function of LPIP, strengthening the role of KPK and sanctions, empowering NGO as the element of policy control, improving interpretation and definition of corruption to protect the state's economy and finance; (ii) public policy control, as a means of prevention of corruption may result in: the increase in demands of policy accountability, the increase in policy transparency, the increase in law enforcement against policy corruption, and the improvement of community's control and participation in supervising the policy.
\end{abstract}

Keywords- Corruption, Legal Politics, Policy.

\section{INTRODUCTION}

Policy refers to a government's actions to accelerate the realization of the state goal, namely providing welfare for its citizens, as mandated by the 1945 Constitution. [1] The founding fathers of this country asserted that this democratic country would be a 'welfare state' (walvaarstaat), not a night watchman state (nachtwachterstaat), while Hatta choose the term 'Negara Pengurus. [2]' A state should put its goal and idea (rechtsidie) as its reference. As a welfare state, Indonesia's main priority is to promote people's welfare. [3] Kenichi Ohmae, in The End of Nation State: The Rise of Regional Economics, argues that nation states (including Indonesia) will face tremendous pressures of global capitalism with its regional economic model, and those without sufficient principles and defense may result in the downfall. [4] Recently, a range of policies deviate from the state's goal. The policy is oriented only to economic sector in order to adjust to the economic globalization, [5] along with the influence of economic globalization. [6] A country in transition period faces a greater risk of the effect of corruption in the economic globalization era. [7] Such policies are influenced by political wills, leading to nonobjectiveness in adjusting to the community's need, meaning that the policies serve only temporary, personal interests. This phenomenon serves as the initial assumption that within a policy, corruptive actions that harm the state. Indonesia is a country with a high corruption level index. Data from International Corruption Watch (ICW) concludes that the state's loss due to corruption in 2018 was Rp. 9.29 trillion. [8]

Statistical data released by Corruption Eradication Commission (KPK) showed that corruption level in Indonesia is very high. Corruption occurs in three sources of authority (executives, legislatives, and judicial). Corruptive behavior becomes trend among state officials recently. With their authorities, officials take policies that benefit themselves. [9] Such a fact concludes that policies are prone to an individual or a certain group's interest, which have the potential to materially and morally harm the state. Although the policy has been in accordance with the procedure and authority, its implementation should be evaluated, whether it benefits, or harms the country.

\section{RESEARCH METHOD}

This paper is categorized library research with deductive reasoning. Statute approach was applied to extend the meaning of corruption delict, comparative approach was applied to compare Chinese law enforcement mechanism in eradicating corruption; while conceptual approach was applied to formulate the concept of policy control as a means of corruption prevention.

\section{FINDINGS AND DISCUSSION}

\section{Legal Political Strengthening in the form of Control toward Public Policies}

First, optimizing the function of government internal supervisory institution. The strengthening of control towards policies can be done through preventive attempts by the Government Internal Supervisory Institution (LPIP) during the policy-making process and through repressive attempts in the form of policy responsibility. Chinese policy control model proves the existence of Supervisory boards. Supervisory Board was established 
by the State Board in 1987, It is responsible for overseeing the Government's Department, state organs and public officials, and maintaining administrative discipline. Supervisory Board possesses the authority to impose administrative sanctions (xingzheng chufen) for cases involving less than 2,000 yuan, starting from a warning until a discharge. Cases that involve more than 2,000 yuan or criminal acts should undergo investigation and be continued to the public prosecutor for the possibility of prosecution. In 1998, following the establishment of the Supervisory Department, the provincial governments establish the supervisory bureau until the county level. Chinese Ministry Center establishes a special bureau that is responsible for supervising industrial fields; financial matters; banking and foreign affairs; government; education and community health; agriculture; and construction and transportation. Also, it establishes three bureaus and a regional office in the government's ministries and the state companies. [10]

Indonesian government's scheme is also followed by the establishment of the Audit Board (BPK-RI) and Government Internal Supervisory Apparatus (APIP) as the internal supervisory board. APIP aims to make sure that governance is implemented according to the state's goal and target. The function and roles of APIP could be optimized. Internal supervision is done through audit, review, evaluation, monitoring, and other supervisory activities toward the organization's duty and functions. This is done to assess the conformity of an activity to the indicators. Furthermore, APIP should perform transformation and evolution to carry out its duty as the value-added for both central and regional governments. This is consistent with APIP's function of carrying out the Government Internal Control System (SPIP) and promoting the effectiveness improvement of risk management, control, and organization's governance in Government Regulation no. 60 of 2008 on Government Internal Control System. [9] With good implementation, APIP may prevent fraud, generate valuable output as suggestions for external auditors, executives, and legislative to improve financial management and accountability in the future. BPK can use APIP's results of the review on the government's financial report, support the regional government to implement BPK's recommendation, and to improve the internal control system. Professional, independent APIP promote transparency and accountability of financial management, improving the fairness of financial report. Mistakes in implementing policy should be compensated by sanctions or punishments. If it is proven to be a criminal act, it should be proceeded by the law enforcers. This is in line with Law no. 28 of 1999 on Governance Free from Corruption, Collusion, and Nepotism.

Second, strengthening the role of KPK and toughen the punishment. In Indonesia, the existence of KPK is full of polemic because the government itself cannot fully accept its presence as an independent anti-corruption institution. KPK always become the target of weakening and intervention by pro-corruption individuals. Model in China can be used as the embryo of the notion of KPK strengthening. Policy control can be done by extending and toughening the punishment of corruption. The implementation: Firstly, the impoverishment of policy corruptors in the form of property seizure so that he/she cannot commit corruption. Impoverishment results in deterrence since the punishment is far greater than the result of their corruption. Impoverishment is also applied to the involving corporations. Corruptors are impoverished by seizing their assets until the state's losses are fully recovered. [11] Secondly, returning the corrupted state assets. This attempt is made specifically for those placed in foreign countries, considering that the law enforcers often find it difficult to take them back to Indonesia. The concept of asset recovery covers tracking, securing, seizing, returning, and maintaining assets. Thirdly, applying social punishment, such as social work to substitute the social loss due to corruption, announcing the perpetrator's name in mass media, and revoking electoral rights.

Third, empowering non-govermental organizations as the element of policy control. Public policy is the meeting point of the government and the community, which is actualized through community participation and the government's role within a policy. E. Vigoda, [12] argues that the evolution process occurs within the interaction between public administration and the community. At the beginning of evolution process, the citizen acts as subjects while public administration as rulers, it shifts to a phase where citizens act as voters and public administration as trustees, then it moves to a phase where citizen acts as clients/customers and public administration acts as managers. Followed by citizens as partners and public administration as partners, and finally, citizens as owners and public administration as subjects. Such an evolution process generates interaction patterns between community (through NGO) and public administrations, which vary in terms of participation community. From political perspectives, such shifts exhibit attraction of power between two parties within a policy. Dynamics of policy formulation in Indonesia is characterized by a huge number of factors relating to the democracy process. [13]

Fourth, extending the interpretation and definition of corruption to protect the state's finance and economy. This classical issue ends in one question, can a policy be punished? Article 50 of Law no. 1 of 1946 on Criminal Code (KUHP) reads: "Not punishable shall be the person who commits an act for the execution of a statutory provision". Article 2 paragraph (1) and Article 3 of Law no. 31 of 1999, as amended by Law no. 20 of 2001, serves as the reference of the element of corruption in practice, there is a confusion in understanding article 2 or article 3 . Delict in article 2 and article 3 are quite complete in classifying a corruption with the focus that corruption harms the state's finance or economy. A law-violating act can be defined as an action that violates the regulatory legislation or in the context of a policy, the element of 
such violations can be viewed. [14] In a policy-making process, it can be assessed whether or not the process conforms to the regulation by viewing, for instance, the authority of the policymakers. The element of abuse of power is attached to policymakers and affect the policy made.

Constitutional Court Decree no. 003/PUU-IV/2006, states that the elucidation of article 2 paragraph (1) of Law no. 31 of 1999, in conjunction with Law no. 20 of 2001 , is not legally binding. The element of 'anyone' in that article refers to those with authority. Thus, one's actions can be considered a law-violating act but do not necessarily mean abuse of power since he/she does not necessarily have the authority. In order to be categorized into article 3, an individual should have authority or function and he/she abuses the authority. In practice, after the issuance of Constitutional Court Decree no. 003/PUUIV/2006, judges still have different perceptions in ruling corruption cases, particularly about when an individual is considered violating article 2 paragraph (1) or Article 3 of Law no. 20 of 2001, in conjunction with Law no. 31 of 1999. Over time, the Supreme Court begins to show the similarity of perspectives, as shown in decree no. 1038 K/Pid.Sus/2015. The Supreme Court argues that the state's loss of more than 100 million will be imposed by article 2 of Law on Corruption. If the public prosecutor employs alternative charge, the judge viewed that article 2 paragraph (1) of Law on Corruption is more appropriate, compared to Article 3 of the Law This ruling is about an employee of Cleaning Department of Medan City. [15]

According to Eddy O.S. Hiariej, [16] there are three cumulative parameters used to justify whether or not a policy is categorized into a crime. Firstly, a policy is used as a 'gate' to commit a felony, it is proven by causality showing that the policy and felony are in a sequence of one criminal act. Secondly, moral hazard is present in the policy-making process. Pompe argues that criminal law does not only deal with juridical mistakes but also moral hazard in a behavior. Moral hazard is associated with one's moral attitude in performing a certain behavior, which is difficult to be proven. Accordingly, using objectified intentionality theory, moral hazard can be viewed based on facts based upon valid evidence. Third, the policy that violates the law or other regulations issued by a public official or a state institution. A number of Supreme Court's jurisprudence are used as references to rule policies. First, Supreme Court Decision dated 15 December 1983 no. 275K/Pid/1982 on Natalegawa case, the Director of Bank Bumi Daya issued a policy that granted real estate credit to PT. Jawa Building, despite knowing Bank Indonesia's Circular Letter that prohibited such a credit. According to BI, violation of the content of the circular letter only result in administrative sanction, however, the Supreme Court decides that the convict violates appropriateness principle of the community so that he was punished due to committing corruption. [16] Second, the Supreme Court decision on Syahril Sabirin's case. In order to smooth Bank Bali's claim of Rp.904.6 billion to BI. Syahril Sabirin, as BI governor, changes joint decision letter (SKB) dated 6 March 1998 to SKB dated 11 February 1999. Another policy he issued is related to the distribution of Rp.6,7 trillion to Century, Financial system stability committee (KSSK) clearly violates BI regulation no. 10/26/PBI/2008 on short-term funding facility (FPJP) provided to banks with Capital Adequacy Ratio (CAR) of a minimum of $8 \%$. While Bank Century's CAR was 2.35 at that time. In November 2008, $\mathrm{BI}$ changes that regulation, which the requirement of a minimum of $8 \%$ CAR for FPJP is turned into only positive CAR. Century's CAR when receiving the fund on 31 October 2008 was $-3.53 \%$. Thus, the third parameter to judge the policy is met. [16]

\section{Public Policy Control as a means of Corruption Prevention}

Good policy is the one that can be accounted both regarding its target and its process. Policy can be very subjective in nature because it contains wisdom of the policy maker. Policy refers to "a purposive course of action followed by an actor or set of in dealing with problem or matter of concern." [17] Meanwhile, wisdom refers to more concrete consideration and covers the area beyond the implementation of the regulation. Policy control will be in line with corruption prevention, which results in:

First, greater demands on policy accountability. Policy accountability should prioritize its benefit and comply with the procedure to prevent formal defects. Policy accountability is done directly its proving attempts should be free from the government's intervention. Accountability has been put as a norm in regulation and consequentially, serves as the judge instrument to investigate and rule a case.

Second, better policy transparecy. Hazel Croall argues that "the inability of victims to detect offense is, of course, the major reason why so much white-collar crime is unreported." The inability to find out the authority's deviation proves that the policy is not transparent. The officials' conspiracy, with or without external parties, may conceal the scandal. [18] Moral formulations are needed to promote a transparent policy. The policy should prioritize moral guidelines in interpreting openness, honesty, and appropriateness according to first and the second Sila as the basis of morality of the nation.

Third, better spirit of law enforcement against policy corruption. Law enforcement against white-collar crimes faces obstacles because the perpetrators use their authority to interfere. [19] Legal process becomes unfair and stand in the side of individuals with higher social capital status. The principle held by this corruptor is "low risk and high profit activity". [20] Law is manipulated and full of dishonesty. The rigor of law may serve as the determining factor. In China, the sweet result of war against corruption during Deng Xiao Ping's period is enjoyed today. [21] 
Chinese criminal code asserts that both bribe giver and bribe taker should be punished. Death penalty for the bribe takers and life imprisonment for the bribe givers become the legitimacy of corruption eradication. Death penalty is also applied to the state's high-ranking officials, not only to low-ranking officials or common individual. Among the officials sentenced to death due to corruption are Cheng Kejie, (Governor of Guangxi Autonomous Region), Ma Xiangdong (Mayor of Shenyang), Li Jiating (Governor of Yunnan), Ma De (secretary of the municipal committee of the Communist Party of China (CPC) in Suihua City, Heilongjiang), and Liu Jinbao (CEO of Bank of China). [21]

Fourth, better community control and participation in supervising policies. Good government involves its community in policy-making and supervising process. [22] In a policy formulation, corruption occurs due to the absence of effective control from the community and poor individual factors and public organization management. [23] Community's poor control may trigger corruption practices. Accordingly, community participation began to be included in regulatory legislations.

\section{IV.CONCLUSION}

The Strengthening of legal politics in the form of policy control can be actualized by: (i) optimizing the function of LPIP, (ii) improving the role of KPK, toughening the punishment, (iii) empowering NGO as the element of policy control, and (iv) extending the definition of corruption to protect the state's finance and economy.

Public Policy Control, as a means of Corruption Prevention, may result in: (i) greater demands on policy accountability, (ii) policy transparency improvement, (iii) better spirit of law enforcement against policy corruption, and (iv) better community control and participation in supervising policies.

\section{REFERENCES}

[1] M. Iqbal, "“Kriminalisasi Kebijakan Pejabat Publik"," Puslitbang Hukum Dan Peradilan Badan Litbang Diklat Kumdil Mahkamah Agung RI, Jakarta, 2014.

[2] Sekretariat Negara RI, Naskah Persiapan UUD 1945: Risalah Sidang BPUPKI/PPKI, Jakarta: Sekretariat Negara RI, 1959.

[3] I Gusti Ayu K. R. H., "'Kedaulatan Sumber Daya Alam Di Indonesia Sebagai Aktualisasi Nilai-Nilai Pancasila," Yustisia, vol. 3, no. 1, pp. 50-56, 2014.

[4] Ohmae Kenichie, The End of Nation State: The Rise of Regional Economics, London: The Free Press, 1995.

[5] Paulus Israwan Setyoko, "'Pelibatan Masyarakat Sebagai Etika Dalam Formulasi Kebijakan Publik Guna Mencegah Praktik Korupsi"," Jurnal Sasi, vol. 3, no. 2, pp. 26-39, 2017.

[6] Jens Bartelson, "“The Concept of Sovereignty Revisited"," The European Journal of International Law, vol. 17, no. 2, pp. 463-474.

[7] Jayoti Das, "“The Nonlinear Impact Of Globalization On Corruption"," The International Journal of Business and Finance Research, vol. 3, no. 2, pp. 33-46, 2009.

[8] Kompas, "Kompas.com," 02 January 2018. [Online]. Available: https://nasional.kompas.com/read/2019/04/28/15294381/icwkerugian-negara-akibat-korupsi pada-2018-capai-rp-929- triliun?page=all. [Accessed 06 July 2020].

[9] Made Sugi Hartono, "“Korupsi Kebijakan Oleh Pejabat Publik (Suatu Analisis Perspektif Kriminologi)"," Jurnal Komunikasi Hukum, vol. 2, no. 2, pp. 212-227, 2016.

[10] Andrew Wedeman, "“The Intensification of Corruption in China"," The China Quarterly, pp. 826-921, 2004.

[11]R. Prasetyo, "“Penyitaan Dan Perampasan Aset Hasil Korupsi Sebagai Upaya Pemiskinan"," Perspektif, vol. 1, no. 12, pp. 149$163,2018$.

[12] Subando A. Margono, "“'Demoralisasi Birokrasi dan Manipulasi Kebijakan Publik: Telaah Pengembangan Kapasitas Untuk Mencermati Lemahnya Governance"," in Reformasi Aparatur Negara Ditinjau Kembali, Yogyakarta, Gava Media, 2010, p. 51.

[13] Wahyudi Kumorotomo, "'Intervensi Parpol, Politik Uang Dan Korupsi: Tantangan Kebijakan Publik Setelah Pilkada Langsung"," Konferensi Administrasi Negara, 15 May 2009.

[14]Zudan Arif Fakrulloh, "“Akuntabilitas Kebijakan Dan Pembudayaan Perilaku Antikorupsi"," Perspektif, vol. 16, no. 2, pp. 105-116, 2011.

[15]Hukum Online, "Hukum Online," 25 February 2017. [Online]. Available:

https://www.hukumonline.com/berita/baca/lt58b107c37432b/mema hami kembali-delik-formil-pada-pasal-2-dan-pasal-3-uu-tipikor/. [Accessed 08 July 2020].

[16]Eddy O. S. Hiariej, "Kompas.com," 02 February 2010. [Online]. Available:

http://library.um.ac.id/majalah/printmajalah5.php/35641.html. [Accessed 08 July 2020].

[17]I Wayan Suandi, "'Eksistensi Kebijakan Publik Dan Dalam Penyekenggaraan Pemerintahan Daerah"," Jurnal Ilmiah Fisip, vol. 1, no. 2, pp. 12-23, 2010

[18]Baharuddin Lopa, Kejahatan Korupsi Dan Penegakan Hukum, Jakarta: Kompas, 2002.

[19]Romli Atmasasmita, Sekitar Masalah Korupsi: Aspek Nasional Dan Aspek Internasional, Bandung: Mandar Maju, 2004.

[20]Gerson W. Bawengan, Pengantar Psychology Kriminil, Jakarta: Pradnya Paramita, 1977.

[21]Ririn Darini, "“Korupsi di China: Perspektif Sejarah"," Informasi, vol. 37, no. 1, pp. 72-81, 2011

[22] Sijaruddin, et. al., Hukum Pelayanan Publik Berbasis Partisipasi Dan Keterbukaan Informasi, Malang: Setara Press, 2012.

[23] Marzully Nur, Denies Priantinah, "'Analisis Faktor-Faktor Yang Mempengaruhi Pengungkapan corporate Social Responsibility di Indonesia (Studi Empiris Pada Perusahaan Berkategori High Profile yang Listing di Bursa Efek Indonesia)"," Jurnal Nominal, vol. 1, no. 1, pp. 1-17, 2012. 